\title{
Religious (de)politicisation in Uganda's 2016 elections
}

\author{
Alava, Henni
}

2017-02-01

Alava , H \& Ssentongo , J S 2017 , ' Religious (de)politicisation in Uganda's 2016 elections '

, Journal of Eastern African Studies , vol. 10 , no. 4 , pp. 677-692 . https://doi.org/10.1080/17531055.2016.1270043

http://hdl.handle.net/10138/218292

https://doi.org/10.1080/17531055.2016.1270043

cc_by_nc_nd

publishedVersion

Downloaded from Helda, University of Helsinki institutional repository.

This is an electronic reprint of the original article.

This reprint may differ from the original in pagination and typographic detail.

Please cite the original version. 


\section{Religious (de)politicisation in Uganda's 2016 elections}

\section{Henni Alava \& Jimmy Spire Ssentongo}

To cite this article: Henni Alava \& Jimmy Spire Ssentongo (2016) Religious (de)politicisation in Uganda's 2016 elections, Journal of Eastern African Studies, 10:4, 677-692, DOI: 10.1080/17531055.2016.1270043

To link to this article: http://dx.doi.org/10.1080/17531055.2016.1270043

(c) 2017 The Author(s). Published by Informa
UK Limited, trading as Taylor \& Francis
Group

Submit your article to this journal

Џll Article views: 316

Q View related articles $\widetilde{ }$

View Crossmark data \lceil

4 Citing articles: 2 View citing articles 


\title{
Religious (de)politicisation in Uganda's 2016 elections
}

\author{
Henni Alava ${ }^{a}$ and Jimmy Spire Ssentongo ${ }^{b}$ \\ ${ }^{a}$ Department for Political and Economic Studies, University of Helsinki, Helsinki, Finland; ${ }^{b}$ Centre for African \\ Studies, Uganda Martyrs University, Kampala, Uganda
}

\begin{abstract}
Religion has influenced Ugandan politics ever since colonial times. While the interrelations of religion and politics have altered since the coming to power of president Museveni's National Resistance Movement (NRM), religion continues to influence Ugandan public culture and formal politics in important ways. Building on ethnographic fieldwork in Kampala and Acholi, as well as analysis of media reporting and discussions in social media, this article focuses on the role of religious leaders during Uganda's 2016 parliamentary and presidential elections. We argue that the striking differences between Ugandan clerics' teaching on politics relate in part to genuine differences in religious beliefs, but also to patronage, intimidation, and ethnicity, and to the strategic calculations religious leaders make about how best to affect change in a constricted political environment. In discussion with previous research on religion and politics in Africa, and utilising analytical concepts from the study of publics, the article proposes a model of religious (de)politicisation, whereby both the politicising and depoliticising effects of religion are acknowledged. To do so, the analysis distinguishes between NGOised and enchanted planes of religion, and shows that on both planes, religion contributed simultaneously to enhancing and diminishing the space for public debate in election-time Uganda. While many religious leaders actively or silently supported the incumbent regime, religious leaders also took vocal public stands, fostered political action, and catered for vernacular imaginaries of political critique, by so doing expanding the space of public debate. However, by performing public debate that remained vague on crucial issues, and by promoting a religious narrative of peace, religious leaders participated in the enactment of a façade of political debate, in so doing legitimising the autocratic facets of Museveni's hybrid regime. Acknowledging religion as an important constituent of public culture contributes to more nuanced understandings of election dynamics in Eastern Africa.
\end{abstract}

\section{ARTICLE HISTORY}

Received 19 August 2016

Accepted 2 December 2016

\section{KEYWORDS}

Africa; civil society; politics; public culture; religion

'No political rally will ever gather the crowds you see gathered in Ugandan churches every Sunday morning.' This statement, made by the Secretary General of the Uganda Joint Christian Council in response to our question about the role of religion in Uganda's 
elections, reflects the highly religious character of public culture in Uganda. Combined, the crowds who gather to pray, praise, and listen to sermons in churches and mosques across the country, far outnumber those attracted by pre-election political spectacles. ${ }^{1}$ In this article, we argue that what religious leaders say and do within these religious spaces and in public debate in Uganda is of consequence for the country's politics: religion serves both to enhance, and to diminish Uganda's 'political proper'.

Our key contention is that as a whole, despite the attempts of many religious leaders towards the opposite, public religion served to depoliticise the elections - that is, to weaken the political proper - what Cochrane describes as the 'space of the public, in which the communicative interaction necessary to subdue and tame the destructive excesses of political power ... becomes possible'. To make this argument, we utilise Gifford's distinction between the plane of 'NGO-ised' religion, which has in recent years increasingly adopted the language and forms of secular donor-funded civil society, and that of 'enchanted' religion, which embraces belief in the power of other-worldly forces to influence this-worldly affairs. ${ }^{3}$ While we argue that depoliticisation took place on both of these levels, we also identify divergent impacts: both as staff of NGOs, and as leaders of communities of enchanted religious imagination, Ugandan religious leaders took vocal public stands, and catered for vernacular imaginaries of political critique, by so doing expanding the political proper in election-time Uganda.

Our analysis proceeds as follows. First, as examples of religious activity on the NGOised plane, we analyse the Inter-Religious Council of Uganda's (IRCU) role in arranging televised presidential debates prior to the elections, and the election monitoring activities of the Uganda Joint Christian Council (UJCC). We claim that while the declared aim of these activities was to entrench democracy, they may in fact have served to entrench the authoritarian side of Museveni's hybrid regime. Second, in discussing enchanted religion, we observe how religious leaders' interpretations and teaching about the source of authority could be employed during election time both to legitimise and to delegitimise political power on the one hand, and popular protest on the other. Similarly, idioms of spiritual or divine influence, and of spiritual warfare can be interpreted both as depoliticising, and as forms of vernacular political critique.

Third, we discuss the considerable diversity in individual religious leaders' positions on the elections. We argue that while this diversity can in part be understood in light of genuine differences in formal doctrine and personal religious convictions, the likelihood of religious leaders to lend support to the ruling regime is importantly moulded by the position of religious leaders in networks of patronage, their vulnerability to state intimidation, and by ethnicity. All of these issues not only pit religious groups against each other, but also feed division within groups, thus weakening their ability and willingness to work as counterweights to state power.

The starting point for our analysis is deliberately normative, in that we consider public debate, and the possibility for citizens to participate in it without fear of violence or discrimination, a desirable feature of any society. This position, and the analysis presented in this article, are informed by our long-term engagement with analysing Ugandan politics as researchers, and in Ssentongo's case also as a regular political commentator, as well as by previous ethnographic research we have conducted in Kibaale ${ }^{4}$ and Kitgum. ${ }^{5}$ The empirical material for this article was gathered during fieldwork conducted around the time of the elections in Kampala and the Acholi subregion. During this time, we observed the 
main service in two Pentecostal, one Catholic, and one Protestant church and in two mosques, in addition to which research assistants took observation notes from 10 places of worship in one Acholi town on the Sunday prior to elections. Alongside numerous informal discussions with Ugandans from different backgrounds, we conducted formal interviews with representatives of the IRCU and UJCC in Kampala; with close to 20 Catholic, Protestant, Pentecostal-Charismatic and Muslim clerics and lay church leaders in Acholi; and with civil society activists in both locations. In addition, we analysed materials produced by the UJCC and IRCU, as well as articles and debates on religious involvement in the elections in local radio, print as well as social media. Due to the safety concerns of some of our informants, their names, and details of dates and locations of interviews are withheld.

\section{Religion, politics and (de)politicisation in Africa}

Scholars on African religion and politics increasingly agree that the two are entangled, and that to understand their significance in African societies, it is necessary to abandon assumptions of the inevitability of the continent's secularisation and democratisation following a 'Western' model. Beyond this consensus there is, however, considerable variation in focus and analytical approach. Research focusing on the state has often looked at the institutionalised relationships of religious elites and the state ${ }^{6}$, or the impact of religion on people's interest in formal politics ${ }^{7}$ or electoral behaviour. ${ }^{8}$ A recurring interest in this research has been the effect of religion on democratisation. Since the 1980s, when mainline churches played key roles in the third wave of democratisation in Africa, churches on the continent have been far less visible for promoting democracy than they have for promoting conservative morality laws. ${ }^{9}$ A number of the reasons behind this shift have relevance for our analysis. First, the opening of political space enabled the emersion of new civil society actors alongside churches, which under totalitarian rule had often been the only ones strong enough to express public discontent (ibid). Second, as Kassimir argues, the transition from one-party dictatorships to multiparty democracies found churches somewhat lost as to what to lobby for next, whereby internal ethnic divisions and patronage ties lessened the likelihood that they would oppose the state. ${ }^{10}$ Third, through their increased engagement in service provision, religious institutions have been increasingly drawn into networks of neoliberal governmentality, decreasing their credibility in the eyes of many of their members, ${ }^{11}$ and intensifying their tendency to replicate patterns of the authoritarian governance found in state institutions. ${ }^{12}$

Parallel to debates about the impact of religion on formal democratisation, and in part triggered by the phenomenal growth of Pentecostal-Charismatic Christianity in Africa, more culturally oriented scholarship has highlighted the importance of religious healing, ritual, community and belief in the lifeworlds of millions of Africans. Seeking to de-stabilise the dichotomies of state-society, public-private, and secular-profane, this research has pushed analysis to explore the political nature of religion in itself. ${ }^{13} \mathrm{At}$ an early point in this debate, Schoffeleers argued that to read politics into apparently apolitical religious expression risks blinding scholars to how symbolic protest in fact 'function [s] so as to discourage rather than encourage active involvement in critical politics' ${ }^{14}$ In response, Bompani prompted scholars to move 'beyond seeing politics exclusively in terms of direct opposition to or support for government policies and institutions' ${ }^{15}$ Thus seen, it 
could be acknowledged that members of churches can be politically active in spite of the apparently apolitical sermons they hear on Sunday mornings. Bompani's point has particular relevance in settings characterised by political repression and volatile divisions, such as Apartheid-era South Africa, and, we argue, contemporary Uganda. In such contexts, for religious leaders to take openly political stands may be ill-advised, not only because of the personal political risks incurred, but because their members fall in opposing political camps. ${ }^{16}$

To draw from literature on the entanglements of religion and both formal and informal politics, we employ Gifford's recent distinction between NGO-ised and enchanted religion. ${ }^{17}$ As we show, following Ellis and ter $\mathrm{Haar}^{18}$, these do not constitute mutually exclusive categories, but rather, exist as parallel and often entangled planes in Ugandan religiosity. Echoing Cochrane, we ask whether, how, and to what extent these two planes of religion can be seen as having provided a 'source of vitality for recovering "the political proper"' 19

Despite utilising concepts that have a decidedly Habermasian ring, we reject the Habermasian view that insists on 'a singular public sphere regulated by a narrowly circumscribed form of rational argumentation'. ${ }^{20}$ Rather, for us the ideal political proper implies a space of debate by multiple voices, employing multiple rationalities and languages; what Gardiner (ibid.) has called a 'wild public'. By acknowledging religion as an integral part of such publics, 'embodied, deeply felt experiences can be represented as coexisting with instances of deliberative and critical reason'. ${ }^{21}$

\section{Religion and politics in Uganda: a multi-faced entanglement}

The intricate entanglement of politics and religion in contemporary Uganda has its roots in the late nineteenth-century Buganda kingdom. Arab Muslims, who were the first to gain influence in the court, were followed in 1877 by the British (Anglican) Church Missionary Society, and two years later the French Roman Catholic White Fathers. ${ }^{22}$ After decades of religious rivalry, the 1900 Buganda Agreement established a tradition whereby Protestants received the largest, Catholics a moderate, and Muslims a circumscribed share of political power. As the Uganda protectorate expanded to include territories beyond Buganda, this pattern of political alignment was transplanted into new territories ${ }^{23}$, and has remained resilient in Ugandan politics to date.

In preparation for Uganda's independence, both the Catholic and the Protestant church lobbied the colonial state and emerging Ugandan political elites to adopt their views on how best to arrange church-state relations in the fledgling nation ${ }^{24}$. By the time of independence in 1962, the newly founded Democratic Party (DP) was popularly known as Diini ya Papa (religion of the Pope), and the Uganda People's Congress (UPC) as the United Protestants of Canterbury. Religious rivalries have, however always been cut across by ethnic and regional divisions. For instance, although the DP was largely a Catholic initiative, it was also strongly identified with Baganda interests, while the Protestant UPC was dominated by Northern Ugandan politicians.

Independent Uganda's presidents have adopted various means to secure the favour of religious leaders while preventing them from exerting control on the state: Milton Obote nationalised church-founded schools, and Idi Amin handed out cars and cash to buy religious leaders' favour while silencing the most critical among them. In 1986, the coming to power of Yoweri Museveni's National Resistance Army/Movement, which identified 
politicised ethnic and religious divisions as one of Uganda's key problems, led to notable changes in Uganda's religious field. Dismantling of multiparty politics weakened the old church-affiliated parties, while increased religious freedom led to a proliferation of Pentecostal-Charismatic churches. Under the NRM, those clerics who have not openly opposed the government have found it relatively easy to operate without intervention or restraint, and those with large followings have also attracted state funding and presidential visits. Religious leaders critical of the government, however, have often been dealt with decisively. During the northern Ugandan war, clergy who spoke out about the government's mistreatment of Acholi civilians were imprisoned, harassed, and some missionaries also deported. Recently, critical political statements by clerics have triggered reminders that religion should not interfere with politics, while, somewhat paradoxically, religious leaders inclined towards the NRM have been appointed by the President to political positions.

In recent years, Museveni's critique of religion as a divisive factor has been increasingly coupled with his praise of religion as a benign collaborator. For instance, in a speech he gave at the born-again all-night New Year's prayers two months prior to the 2016 elections, Museveni declared that in coming years, religious groups would receive increased state funding, 'because they have helped the state to police the minds of its people instead of just depending on policing of the body'. ${ }^{25}$ The fact that the statement was made at a born-again event was no mere coincidence. Ugandan religious and political argumentation has in recent years become increasingly pentecostalised, as seen for instance during debates about 'anti-gay' legislation. ${ }^{26}$ Although the division between the Catholics and the Protestants continues to have some degree of resonance, religious affiliation in contemporary Uganda does not translate directly into either a pro- or anti-government position. The NRM thus has to curry favour from religious leaders across a broad religious spectrum.

\section{NGO-ised religious actors in the 2016 elections}

In the week prior to the 2016 elections, bishops seemed to be everywhere. We met one in a bank for instance, speaking from the television pinned to the corner of the room to an attentive crowd of some 30 people on behalf of the Uganda Joint Christian Council (UJCC). The bishop's message - that it was important to vote, to vote wisely, to stay calm, and to pray for peace - was repeated in the pre-election weeks on TV screens, front pages of newspapers, on radio stations, and in churches and mosques, across the country. We argue that this lobbying, particularly its most prominent forms; the arranging of the presidential debates, and the UJCC's election monitoring activities; both politicised the elections by expanding the space for public debate, and depoliticised the elections by shutting down debate through an over-emphasis on peace, similar to what was witnessed in Kenya's 2013 elections. ${ }^{27}$

While the pamphlets and statements of both the UJCC and the Inter-Religious Council of Uganda (IRCU) are peppered with statements which refer to the divine mission of religious communities, the bulk of the language used by these organisations in their statements, and by their staff in our interviews, echoes rather standard discourse of 'secular' donor-funded civil society actors. The two umbrella bodies thus provide prime examples of NGO-ised religion. The UJCC, founded in 1964, has three member churches: the Catholic, the Protestant and Uganda's small Orthodox Church. In addition to these, the 
IRCU, formed in 2001, includes the Uganda Muslim Supreme Council, the Seventh Day Adventists and two different federations of Pentecostal churches. During the first decades of the UJCC's existence, the conflictual relationship between Catholics and Protestants, as well as extensive political repression, rendered the umbrella body rather ineffectual. ${ }^{28}$ In recent years, spurred on by the waning of church-affiliated political parties under the NRM regime, and the drastic growth in donor funding for 'faith-based' development in the 1980s and 1990s, both organisations have, however, gained in prominence. Two issues in particular have drawn their attention: 'morality laws', including the 'anti-gay bill', and good governance and democracy. The turning point for the latter form of activism was 1994, when the UJCC gathered over half a million US dollars from donors to conduct election observation and civic education around the elections for the re-introduction of political parties (ibid.) The organisations' outspoken support for the anti-gay legislation can be seen as another kind of turning point: in 2014, USAID withdrew a grant which had covered $90 \%$ of the IRCU's funds, leading to the entire IRCU staff being laid off. The UJCC also came to the 2016 election monitoring mission with considerably fewer funds than previously.

In the previous two elections $(2006,2011)$, UJCC conducted election monitoring together with a consortium of civil society actors under the Democracy Monitoring Group (DEMGROUP), but in 2016 the UJCC stood alone. According to UJCC's Secretary General, Father Sylvester Arinaitwe, the Council felt the joint coalition had adopted an overly partisan, pro-opposition attitude, for which reason it was better for churches to distance themselves so as to develop their 'own unique voice'. Both the UJCC and the IRCU systematically foster a non-partisan image. For instance, the retired Bishop Zac Niringiye of the Church of Uganda was advised to leave his chair in UJCC when he became actively involved in social justice activism. But there is also resistance to explicitly pro-government stances: the UJCC has declined Pentecostal churches membership due to their being too openly partisan and having few structures for internal control.

The two bodies' precarious balancing act, between being non-partisan and being completely noncommittal, was played out in a curious way after the 2016 elections. In a press release one week after the elections, the UJCC drew on their election monitors' reports to level critiques very similar to those made by the EU election observers, ${ }^{29}$ concerning for instance the belated opening of polling stations; missing ballots; and the declaration of results without tallying in certain constituencies. ${ }^{30}$ The UJCC also raised concerns over Kizza Besigye's detainment, arguing that it 'constitute[d] impunity on the part of the State'. Furthermore, they argued that the harsh security measures had 'robbed the presidential election ... of a level playing field, its key elements being freedom of movement, of assembly, of expression and the right to equal protection of the law. ${ }^{31}$

While the UJCC's preliminary statements (curiously, no final report has to date been published) retain a modicum of critical edge, some of the statements made by the IRCU and UJCC after the elections bring to mind Gifford's claim concerning Catholic pastoral letters, which often operate on 'a level of generality ... that make them almost evasions. ${ }^{32}$ What further nullified the impact of critique by the UJCC or IRCU were statements made by individual religious leaders. Notably, the Archbishop Stanley Ntagali, who sits on the Council of Presidents of the IRCU and is Chairperson of the UJCC, congratulated Museveni over his victory already before the petition challenging the elections in the Supreme Court was disposed of. Once the petition was dismissed, 
Ntagali stated that this proved that Museveni was indeed 'lawfully elected and is a leader chosen by the Almighty God'. ${ }^{33}$ An image circulating on social media soon after Ntagali's statement contained two pictures of the bishop; one with his mouth open, with the caption 'When asked to comment on gay issues' and another with his mouth tightly shut, with the text 'When asked about oppression and election fraud issues.'

While many of both the clergy and non-clergy that we spoke with felt it was important for clergy to remain polite towards political leaders and to remain non-partisan in their statements, many also expressed frustration over the vagueness of clergy's position. Some Protestant, Catholic and Islamic clergy, drawing on joint discomfort with the compromised silence and vagueness of the IRCU and UJCC, have launched an independent pressure group, Religious Leaders United for Peace and Justice, under the leadership of the retired Bishop Zac Niringiye. While the group sees itself as playing the true prophetic role beholden of religious leaders, the UJCC and IRCU have distanced themselves from it, blaming it for partisan activism.

Both the IRCU and the UJCC mostly operate at the national level, through press statements and direct dialogues with law- and policy-makers in Kampala. On paper, both organisations have regional bodies, but these have no paid staff and very little if any funding. Members of the local body of the IRCU for Acholi subregion for instance told us that the committee had never sat for a meeting. IRCU staff from Kampala came to hold election training for religious leaders from the greater North, so as to enable them to train others. No such 'trickle-down' trainings had, however, been held. Similarly, the UJCC's election observation was theoretically implemented by subregional Ecumenical Joint Action Committees (EJAC). A week before the elections, representatives of UJCC member churches in Gulu told us that the local EJAC was 'in the process' of identifying election observers for the district; whereas in Kitgum, no information or guidance from either the IRCU or UJCC reached local clergy. There were, however, individual initiatives at a local level. For instance, Pentecostal pastors in Kitgum hosted a radio debate for local candidates, and gathered religious leaders from different churches for a call-in show focusing on voter education, and for daily prayers for peace in the week prior to the election. It would appear that at a local level, local initiatives may have been far more significant than national-level networks, the impact of which reaches grassroots clergy largely in the same way it does other Ugandans: through national media. ${ }^{34}$

On January 8th and February 12th of 2016, the IRCU, together with the Elders Forum of Uganda, arranged the first ever televised presidential debates in Uganda so as to 'provide a balanced space for all the presidential candidates to sell their agenda to all the Ugandans and to make a commitment to peaceful and violence-free 2016 general elections. ${ }^{35}$ The debate was applauded in Ugandan media and public discussions as a vital step in the country's democratisation process. But the significance of the debates appears also to have been somewhat ironical, as was inadvertently expressed in an article published by the government-owned New Vision, which declared that '[h]osting the debate ... portrayed the country as democratic'. ${ }^{36}$

Considering the violence witnessed in some parts of the country around the elections, the securitisation and monetisation of the campaigns, and Besigye's extended house arrest, one can ask whether this portrayal of democracy was reflective of reality. At least the crowd gathered to watch the second debate at a bar in Kitgum broke out in incredulous laughter when the presidential candidates joined hands in prayer. This was a powerful 
symbol of what religious leaders wanted to push for during the pre-election period: peace and unity. But at what cost? As Smith has written 'peace is itself a fraught concept that often conceals the violence upon which apparent peace depends' ${ }^{37}$ So also we contend that the peace narrative of Uganda's religious leaders underemphasised the violence that undergirds Uganda's contemporary 'peace'.

Whereas many of the official documents of the two organisations emphasise peace and justice, the majority of media messages and, from the evidence we gathered, homilies in churches and mosques, prioritised peace over justice. Clerics' calls for peace blended well with the state's heavy deployment of security forces during and after elections in the name of ensuring peace. The state's silencing of legitimate political resistance thus benefited from the peace narrative cultivated by religious leaders. When we raised this argument in interviews, many religious leaders responded by highlighting that peace was a priority, because its alternatives were worse. As understandable as this position was, we argue that considering how only a few years earlier, prominent religious leaders had vocally opposed the amendment of term limits ${ }^{38}$, the extent to which peace trumped all other concerns in 2016 is striking. It seems that once it became clear that Museveni was not going to step down, a considerable part of Ugandan religious leaders opted to focus on either securing their own positions, or on fending off the chaos many people feared would erupt if Museveni lost the vote.

To elucidate this point, it is worth looking at how, in order to convince Museveni to come for the second presidential debate, the organisers had to agree that their most sharp-tongued moderator would not pose him any questions. An IRCU representative we interviewed defended this concession as "part of the "give and take" meant to make everyone feel comfortable'. The statement is, we suggest, indicative of a more general characteristic of the relations between religious leaders and the state in Uganda. In order to succeed in engaging the president in discussion, religious leaders must ensure they do not make him uncomfortable. Hence, just as the most outspoken of the moderators was silenced by IRCU, so religious leaders generally silence themselves. This is the 'give and take' of Uganda's hybrid regime: to enable continued engagement with the state, public figures must refrain from saying things the state does not wish to hear.

\section{(De)politicisation through enchanted religion}

The religious leaders we interviewed were on a whole highly adept at using NGO-ised language about the elections. But what was notable was the fluidity with which many of them shifted register, from NGO-ised to enchanted language, as soon as we asked whether God, the Devil, or spirits had anything to do with the issues we were discussing. Stories of politicians going underwater, of committing sacrifices, and of visiting traditional healers and diviners in order to gain power, are a powerful currency in political debate - in Uganda, as elsewhere in Africa. ${ }^{39}$ As Ellis and ter Haar have argued, in many African epistemologies of power, the material and the immaterial 'cannot be separated, although they can be distinguished from each other'. ${ }^{40}$ Indeed, as the clerics showed with their shift from one register of language to another, the enchanted and NGO-ised planes of religion - and of religious actors' political engagements - exist comfortably alongside each other in Ugandan public culture. In this section of the article, we argue that engagements with politics on an enchanted level can both expand and diminish the space for public debate. To 
make this claim, we first analyse Ugandan religious leaders' political theologies pertaining to authority, and then discuss the ways in which a spirit idiom was employed to political analysis in election-time Uganda.

Two distinct strands appear in the political theologies employed by religious leaders in relation to politics and the elections. The first of these emphasises the divine origin of political authority, an argument put to us by both PCC, Protestant, Catholic and Muslim clergy. One example of this was presented in a WhatsApp message distributed by a Catholic priest to a group to which one of the authors belonged, in which he urged Ugandans not to take power in their own hands, since 'Museveni might have rigged elections but I think God let him do it for reasons that remain with him.' In a similar vein, one Acholi Pentecostal pastor gave a sermon about leadership some time prior to the elections:

There is something about our nation: we have a spirit of rebellion. We have a really big problem with authority! They say 'let's have buses', you say, 'no problem, we will walk to work!'. We think we understand authority, but we do not know how to submit to authority.

The sermon's allusion to the Walk to Work protests staged after the 2011 elections were more than clear - clear also was how the theological emphasis on submission to authority contributed to forming a narrative of stability and peace. At the end of the sermon, the pastor insisted that Christians were facing a choice between God and the Devil. If the Devil was unleashed, the teargas people had seen would seem like nothing. By condemning unrest on the streets, and emphasising the idea of God as a 'God of order', the pastor constructed the political opposition as the Devil, and the election as a time for Christians to choose submission over anarchy. In an interview, the pastor elaborated:

It's wrong to use your pulpit for hooliganism. God is in control, he is not unaware. There is no political leader who did not get there without God's plan, whether rigging or what. God is not unaware.

In contrast to such views, which posited earthly authority as having a divine source and hence being unobjectionable, the second line of argumentation we encountered distinguished between two types of authority. As one Catholic priest described:

The question of where authority comes from depends on the kind of authority. Self-imposed authority is not from God. Authority gained from the rigging of elections does not come from God. When you use the gun from government, you can't say it's from God. Then you get authority from the gun, from killing, from suppressing the people. Almost from the Devil.

A Pentecostal pastor similarly argued that while some leaders 'gain authority through the gun', genuine authority from God 'comes progressively, not just all at once.' Those religious leaders who distinguished between authority given by God, and authority taken by man, tended to also emphasise that like the Prophets of the Old Testament, religious leaders are ordained to 'speak truth to power', that is, to reprimand those who abuse their power to the detriment of those they lead.

In addition to distinctly different doctrinal views on political theology, the clerics we interviewed also differed in their views on the extent to which spirits, demons and witchcraft influenced Ugandan politics. Some of the interviewees saw politics as thoroughly enchanted, to use Gifford's term. ${ }^{41}$ One Pentecostal pastor for instance explained:

What I know very well is that the spirit of the demons can influence the elections. Because most of the politicians are nominal Christians, they will ask for help from the demons. Most 
in fact do; they go to witchcraft in order to win. Most leaders are led by demons. Very few are truly Christian.

The perceived moral and spiritual corruption of politicians impinged a serious responsibility upon born-again believers, as another pastor explained:

A person can be taken up; a nation can be taken up, if God's people don't stand up in prayer and spiritual warfare. If the people of God relax and don't stand in the gap in prayers, our leaders and the nation will be taken up by the Devil.

A few days prior to the elections, another pastor stated that nothing could be done to change the outcome of the election, or the violence that would take place, because crucial spiritual battles had already been lost weeks ago due to insufficient prayers. He however encouraged his parishioners to continue fasting and praying, since God alone could change Uganda. Such accounts do not make clear whether it is in fact otherworldly forces, or peoples' prayers, that influence political outcomes, yet what is clear is that they encourage enchanted action over political mobilisation.

Echoing Schoffeleers, we could argue that such enchanted religion had a depoliticising effect on the 2016 elections. ${ }^{42}$ However, we hold that such a conclusion would be premature, for two reasons: first of all, those clerics who expressed the belief that spirits were influencing the elections, often also expressed very clearly articulated 'secular' political arguments. The enchanted and the NGO-ised planes of religious and political argumentation and action do not necessarily cancel one another out. A pastor can pray for peace and engage in spiritual battle with the forces of division in the morning, and give a radio talk show on civic duties and democracy in the afternoon.

Secondly, while they may direct engagement away from formal political channels, enchanted understandings of politics can also contribute to expanding the space for public debate. Some of the claims we heard from religious leaders; that it was the spirits of violence and confusion that were causing the irregularities and violence around the elections; that Museveni was so powerful because he was resorting to magic to remain in power; or that he could not be toppled because he was anointed by God; clearly did not contribute to the birth of the ideal Habermasian 'rational-deliberative' public. But as Englund $^{43}$ has argued, they did contribute to the creation of public culture, or what Gardiner ${ }^{44}$ terms a wild public which is marked by a multiplicity of different voices and rationalities. As our examples have shown, whether multiple enchanted voices contribute to entrenching state power, or to delimiting it, is not a straight-forward question.

In sum, we claim that enchanted religion played a significant but ambivalent role during the 2016 elections. As Deacon has argued for Kenya, it is precisely the non-specificity of spiritual idioms, prayers and spiritual warfare that enables their use when other kinds of public expressions are limited by a repressive political regime. ${ }^{45}$ Yet we also argue that enchanted religious expression cannot be romanticised as a form of inchoate resistance. While it can expand public debate, it can also be employed to clamp it down, and hence to entrench the excesses of state power: in Uganda's 2016 elections, both tendencies were identifiable.

\section{Exploring the diversity of religious leaders' positions}

In the final part of the article, we distinguish factors which we believe explain some of the diversity of religious leaders' political outlooks and actions in election-time Uganda. As we 
have argued above, belief systems affect the ways in which the world is perceived and acted upon. But theological arguments can also be contrived post-fact, as justifications for actions taken. Hence we suggest that it is necessary to look beyond proclamations of belief alone, to what Burchardt et al. ${ }^{46}$ characterise as the pragmatic political calculus that belies religious leaders' actions in Uganda, and to acknowledge the impact of patronage, intimidation and ethnicity on religious leaders' decisions to lend or deny active support to the ruling regime.

The Ugandan state has established itself as a fountain of privileges for religious leaders a strategy rendered all the more effective after cutbacks of donor funding. ${ }^{47}$ Examples of this can be drawn from across the religious spectrum. The Protestant Archbishop Ntagali's public congratulations to Museveni, which we discussed above, were made at the opening of a bishop's house at which the president donated cash to the church and pledged more. In social media, Ntagali's views were likened to the silence of the Catholic Archbishop of Kampala, Lwanga, in the months prior to the elections. Many Ugandans believe that Lwanga, often an outspoken government critic, was tamed by Museveni's donation of 217,000 euros for the refurbishment of the Namugongo shrine prior to the Pope's 2015 visit. $^{48}$ Another blatant exposé of religious patronage was staged at the launch of IRCU's week of pre-election peace prayers at the National Mosque in Kampala. Museveni showed up waving a land title of a mosque in Kampala that has been subject to dispute among two rival Muslim groups, which he said the Muslims could have back as soon as the largely political disputes between them were resolved. In response, the Mufti urged the gathered crowd to 'vote for those who support Islam'.

Religious vote-buying occurs also at local levels, as when local council and parliamentary candidates hand out money and other contributions at religious events, in response to which they are prayed for. Among the many stories we heard of attempts to bribe religious leaders to speak for particular candidates, the most striking was one we heard from a Catholic priest according to whom a representative of the NRM had attended a diocesan priests' meeting prior to the elections, and allegedly handed out each of the approximately 60 priests in the diocese 640,000 UGX (approximately 190 USD). Allegedly, the NRM representative said he had come to the Catholics himself, since unlike others, they had not themselves run to State House. A lay leader of the Church of Uganda maintained that it was difficult for their clergy to keep an independent political stand when they were so poor. Indeed, religious leaders' vulnerability to patronage-based political coercion differs based on their access to alternative sources of income.

One of the high-ranking officials at a religious umbrella body whom we interviewed stated that 'while Idi Amin would use the gun to silence critics, Museveni uses money'. But the heavy deployment of security officials around Uganda during the 2016 elections bears witness to the state's continued use of the gun and other intimidation, also within Uganda's religious arenas. Many of our interviewees believed that their sermons were listened to and that they would be reported to security officers if they were too unpleasantly political. Some claimed to know that there were NRM cadres spying among them, and acknowledged that they were very careful about speaking out about politics in the presence of colleagues they did not know extremely well. Interviewed clerics suspected that being too outspoken included could lead to them losing their operating licences or their tax reductions, having their electricity cut off, or simply disappearing.

A further factor at play in moulding religious leaders' political positions is ethnicity, and the personal and collective experiences that arise from different groups' relationships 
to the central state. This came out particularly clearly in our interviews with Pentecostal pastors, who as a whole are seen as being particularly pro-NRM. This is a view also willingly advanced by the government, as when the government-owned New Vision reported of a gathering of 5000 Born-Again Pastors all pledging support to the incumbent president prior to the elections. However, as many Acholi Pentecostal pastors told us, perceptions of pastors from different parts of the country vary greatly, something they described as at times creating tensions in national meetings of their churches' leaders. Here again, however, the picture is diverse: just as religious affiliation and political views do not necessarily correlate, so also is the case for ethnicity. One Acholi pastor heavily criticised those of his colleagues who advocated openly pro-opposition views, and elaborated:

Sometimes the reasons and motives [for protesting] are wrong. We the Acholi here, it is difficult for us to accept Museveni as the leader. But it was ordained like that.

On a national level, religious leaders' political manoeuvers are also impacted by strategic considerations of how best to reach desired ends. This was particularly emphasised by the UJCC and IRCU, who argued that remaining diplomatic was a key to their ability to effect change. Talking to political leaders in privacy, we were told, helps inhibit resistance and denial, which is why the umbrella bodies 'do a lot of work behind curtains that people may never get to know about'. The pragmatic value of a silent and diplomatic approach may of course be considerable, since confrontational clergy have often been openly condemned and sidelined by government. However, in light of the view that a public space is needed in which 'the communicative interaction necessary to subdue and tame the destructive excesses of political power ${ }^{49}$ can operate, the religious leaders' argument becomes untenable. In fact, we argue that in Uganda, remaining quiet so as to stay on good terms with an autocrat has implied submission to autocracy.

\section{Conclusion: paradoxes of religious political engagement in a hybrid regime}

While some Ugandan religious leaders have actively lobbied for the incumbent regime, or silently condoned its authoritarian practices, others have sought to expand public debate by voicing popular concerns. During the 2016 elections, Uganda's religious umbrella bodies' proclaimed efforts to contribute to democratisation were diluted by their cultivation of a peace narrative, which the state co-opted to serve its interest in maintaining the status quo through repression of political opposition. By performing public debate that remained vacuous and vague on numerous crucial issues, religious leaders have in fact participated in the enactment of a façade of deliberative democracy during the 2016 elections, in so doing subverting the political proper, and legitimising the autocratic tendencies of the hybrid Ugandan state.

Acknowledging religion, in both its NGO-ised and enchanted forms, as an important constituent of public culture, contributes to more nuanced understandings of election dynamics in Eastern Africa. Our analysis suggests that if research is limited to only that level of religious activity which secularised scholars can easily relate with due to its NGO-ised familiarity, it risks missing the variety of ways in which people actually conceptualise and act upon formal politics and how religious experiences can coexist with 'deliberative and critical reason'. ${ }^{50}$ Furthermore, we have emphasised that while religion can 
depoliticise; suppress public debate and undermine the political proper; it can also politicise, contributing important additional voices to the wild public ${ }^{51}$ of the political proper. ${ }^{52}$

Although our analysis of the elections suggests that the overall impact of public religion has been to entrench the authoritarian face of Museveni's hybrid regime, religious idioms that explain political power as an outcome of collaboration with malevolent spiritual forces also provide a language for political critique in an environment where political debate is highly constricted. Indeed, there are elements in Ugandan public religion that may, under different political constellations, serve different ends to the ones they do now. Whether religious leaders gear themselves to support transformation or stability, and whether they succeed in pulling along their followers to do the same, will have important impact on the tone of political transition once Museveni's presidency eventually comes to an end. That time, however, is not yet.

Most of those we spoke with prior to the elections, regardless of their political allegiances, believed Uganda was not yet ripe for change. Such sentiments were particularly prevalent among research participants in northern Uganda, where many people have opted to try and stay under the radar of the state, drawing what benefit they can from a violently enforced peace and the trickles of development that Museveni has allowed to reach the country's peripheries. This sense of patient waiting was summed up by the hymn with which an Acholi Catholic choir began their practice once the polling stations had closed on the day of the elections:

Have we trials and temptations? Is there trouble anywhere? We should never be discouraged!

Take it to the Lord in prayer.

After 30 years of one-man-rule, many Ugandans feel they have no choice but to join their religious leaders in prayer for a time when the trials and trouble of Museveni's regime will be replaced by something hopefully sweeter.

\section{Notes}

1. According to the 2014 census, Catholics number 39.3; Protestants (Church of Uganda) 32.0; Moslems 13.7; and Pentecostals $11.1 \%$ of the Ugandan population, while only $1 \%$ define themselves as non-religious (Uganda Bureau of Statistics 2016). Of those Ugandan who self-identified as Christian, $85 \%$ claimed to attend a religious service at least once a week (Pew Research Centre 2010). In this article, we follow the practice common in Uganda, whereby those belonging to the Church of Uganda, a member of the Anglican Communion, are referred to as Protestants.

2. Cochrane, "Health and the Uses of Religion," 176-77.

3. Gifford, Christianity, Development and Modernity.

4. Ssentongo, "Spaces for Pluralism in 'Ethnically Sensitive' Communities."

5. Alava, "There is Confusion."

6. Hansen, "Mission, Church and State."

7. Manglos and Weinreb, "Religion and Interest in Politics."

8. Takyi, Opoku-Agyeman, and Kutin-Mensah, "Religion and the Public Sphere."

9. Gifford, The Christian Churches.

10. Kassimir, "The Social Power of Religious Organization," 77.

11. Christiansen, "Development by Churches, Development of Churches."

12. Burchardt, Patterson, and Rasmussen, "The Politics and Anti-Politics."

13. Bompani and Frahm-Arp, "Development and Politics from Below"; Comaroff and Comaroff, Of Revelation and Revolution; Ellis and Haar, "Religion and Politics"; Englund, Christianity and Public Culture.

14. Schoffeleers, "Ritual Healing and Political Acquiescence," 3. 
15. Bompani, “African Independent Churches," 665.

16. Ibid., 670 .

17. Gifford, Christianity, Development and Modernity.

18. Ellis and ter Haar, Worlds of Power.

19. Cochrane, "Health and the Uses of Religion," 176.

20. Gardiner, "Wild Publics and Grotesque Symposiums," 44.

21. Englund, Christianity and Public Culture, 8.

22. Kabwegyere, People's Choice, People's Power.

23. Karugire, A Political History of Uganda, 13.

24. Gingyera-Pinycwa, Issues in Pre-Independence Politics.

25. Kasozi, "Museveni Promises Funding to Churches."

26. Alava, "Homosexuality, the Holy Family"; Bompani, "For God and For My Country"

27. Cheeseman, Lynch, and Willis, "Democracy and Its Discontents."

28. Gifford, African Christianity, 152.

29. EUEOM, "Final Report."

30. UJCC, "Preliminary Report."

31. Ibid., 5 .

32. Gifford, Christianity, Development and Modernity, 92.

33. Rumanzi, "Museveni Vows to Crush Protesters."

34. The Catholic Church is an exception to this rule, since their clergy regularly receive and distribute materials produced by the Catholic hierarchy. For example, one Catholic parish in Kitgum sold 120 copies of the Catholic Church's Pastoral letter on the elections, and read parts of it out in church services.

35. IRCU, "Press Release."

36. Emodek, "The Voice of Peace in the 2016 Polls."

37. Smith, "Religious Dimensions of Conflict and Peace.", 3.

38. Dowd, Christianity, Islam, and Liberal Democracy, 112-3.

39. See note 18 above.

40. Ellis and Haar, "Religion and Politics," 387.

41. Gifford, Christianity, Development and Modernity.

42. Schoffeleers, "Ritual Healing and Political Acquiescence."

43. Englund, Christianity and Public Culture.

44. Gardiner, "Wild Publics and Grotesque Symposiums."

45. Deacon, "Driving the Devil Out."

46. See note 12 above

47. See note 41 above.

48. Office of the Prime Minister, "President Museveni Contributes."

49. See note 2 above.

50. Englund, Christianity and Public Culture, 8.

51. See note 44 above

52. Cochrane, "Health and the Uses of Religion."

\section{Acknowledgements}

The authors wish to thank Richard Vokes and Sam Wilkins for organising the 'NRM regime in the 2016 elections' workshop, and the workshop participants' for their comments on our initial research findings. Warm thanks also to Ibrahim Abraham, Jenni Mölkänen, Elina Oinas, LiinaMaija Qvist, Tuomas Tammisto, Mika Vähäkangas and Heikki Wilenius, for comments on earlier versions of the article. Finally, we owe our sincere thanks to the many people who shared their views with us in Uganda, and to research assistants who took notes at church services we were ourselves unable to attend. 


\section{Disclosure statement}

No potential conflict of interest was reported by the authors.

\section{Funding}

Henni Alava's work was supported by the Justice and Security Research Programme (JSRP), based at the London School of Economics and Political Science. The JSRP is funded by DFID under Grant number [PO5729]. However, the views expressed in this article do not necessarily reflect the UK government's official policies.

\section{References}

Alava, Henni. "Homosexuality, the Holy Family and a Failed Mass Wedding in Catholic Northern Uganda." Critical African Studies 9, no. 1. (2017): 1-20.

Alava, Henni. "There is Confusion. The Politics of Fear, Silence and Hope in Catholic and Protestant Northern Uganda." PhD diss., University of Helsinki, 2017.

Bompani, Barbara. "African Independent Churches in Post-Apartheid South Africa: New Political Interpretations*." Journal of Southern African Studies 34, no. 3 (2008): 665-677.

Bompani, Barbara. "For God and For My Country': Pentecostal-Charismatic Churches and the Framing of a New Political Discourse in Uganda." In Public Religion and the Politics of Homosexuality in Africa, edited by Adriaan van Klinken and Ezra Chitando, New edition. Burlington: Routledge, 2016.

Bompani, Barbara, and Maria Frahm-Arp, eds. Development and Politics from Below: Exploring Religious Spaces in the African State. Houndmills: Palgrave Schol, Print UK, 2010.

Burchardt, Marian, Amy S. Patterson, and Louise Mubanda Rasmussen. "The Politics and AntiPolitics of Social Movements: Religion and HIV/AIDS in Africa." Canadian Journal of African Studies / Revue Canadienne Des Études Africaines 47, no. 2 (2013): 171-185.

Cheeseman, Nic, Gabrielle Lynch, and Justin Willis. "Democracy and Its Discontents: Understanding Kenya's 2013 Elections." Journal of Eastern African Studies 8, no. 1 (2014): 2-24.

Christiansen, Catrine. Development by Churches, Development of Churches. Institutional Trajectories in Rural Uganda. Copenhagen: University of Copenhagen, 2010.

Cochrane, James R. "Health and the Uses of Religion: Recovering the Political Proper?" In Development and Politics from Below: Exploring Religious Spaces in the African State, edited by Barbara Bompani and Maria Frahm-Arp. Houndmills: Palgrave Schol, Print UK, 2010.

Comaroff, Jean, and John L. Comaroff. Of Revelation and Revolution. Volume 1, Christianity, Colonialism, and Consciousness in South Africa. Chicago, IL: University of Chicago Press, 1991.

Deacon, Gregory. "Driving the Devil Out: Kenya's Born-Again Election." Journal of Religion in Africa 45, no. 2 (2015): 200-220.

Dowd, Robert A. Christianity, Islam, and Liberal Democracy: Lessons from Sub-Saharan Africa. New York: Oxford University Press, 2015.

Ellis, Stephen, and Gerrie ter Haar. Worlds of Power: Religious Thought and Political Practice in Africa. Oxford: Oxford University Press, 2004.

Ellis, Stephen, and Gerrie ter Haar. "Religion and Politics: Taking African Epistemologies Seriously." The Journal of Modern African Studies 45, no. 3 (2007): 385-401.

Emodek, Jacquiline. "The Voice of Peace in the 2016 Polls." New Vision. 29 February 2016.

Englund, Harri. Christianity and Public Culture in Africa. Athens: Ohio University Press, 2011.

EUEOM. "Final Report. Uganda Presidential, Parliamentary and Local Council Elections 18 February 2016." European Union Election Observation Mission, 2016. http://eeas.europa.eu/ eueom/missions/2016/uganda/pdf/uganda-fr-forprint-14-04-2016_en.pdf.

Gardiner, Michael E. "Wild Publics and Grotesque Symposiums: Habermas and Bakhtin on Dialogue, Everyday Life and the Public Sphere: Wild Publics and Grotesque Symposiums." The Sociological Review 52 (2004): 28-48. 
Gifford, Paul, ed. The Christian Churches and the Democratization of Africa. Leiden: Brill, 1995. Gifford, Paul. African Christianity: Its Public Role. Bloomington: Indiana University Press, 1998. Gifford, Paul. Christianity, Development and Modernity in Africa. London: Hurst \& Company, 2015.

Gingyera-Pinycwa, A. G. G. Issues in Pre-Independence Politics in Uganda. A Case-Study on the Contribution of Religion to Political Debate in Uganda in the Decade 1952-1962. Kampala: East African Literature Bureau, 1976.

Hansen, Holger Bernt. Mission, Church and State in a Colonial Setting: Uganda 1890-1925. London: Heinemann, 1984.

IRCU. "Press Release: The Presidential Debate.” Inter-Religious Council of Uganda, 2016. https:// ircu.or.ug/press-releases/press-release/.

Kabwegyere, Tarsis B. People's Choice, People's Power: Challenges and Prospects of Democracy in Uganda. Kampala: Fountain Publishers, 2000.

Karugire, Sam R. A Political History of Uganda. Nairobi : Heinemann, 1980.

Kasozi, Ephraim. "Museveni Promises Funding to Churches." Daily Monitor. 2016, 2 January edition. http://mobile.monitor.co.ug/specialreports/elections/Museveni-promises-fundingchurches/-/2471424/3018126/-/format/xhtml/-/ivgad2z/-/index.html.

Kassimir, Ronald. "The Social Power of Religious Organization and Civil Society: The Catholic Church in Uganda." Commonwealth \& Comparative Politics 36, no. 2 (1998): 54-83.

Manglos, Nicolette D., and Alexander A. Weinreb. "Religion and Interest in Politics in Sub-Saharan Africa.” Social Forces 92, no. 1 (September 2013): 195-219.

Office of the Prime Minister. "President Museveni Contributes Another 400 Million to Renovate Namugongo Martyr's Shrine.” News Archive, 20 August 2015, 2015. http://opm.go.ug/newsarchive/president-museveni-contributes-another-400-million-to-renovate-namugongomartyrs-shrine.html.

Pew Research Center. "Worship Attendance Uganda. Data Explorer - Pew-Templeton Global Religious Futures Project." Uganda, 2010. http://www.globalreligiousfutures.org/explorer/.

Rumanzi, Perez. "Museveni Vows to Crush Protesters." Daily Monitor. April 4. http://www. monitor.co.ug/News/National/Museveni-vows-crush-protesters/-/688334/3144726/-/ysnu5w/-/ index.html.

Schoffeleers, Mattew. "Ritual Healing and Political Acquiescence: The Case of the Zionist Churches in Southern Africa." Africa (Edinburgh University Press) 61, no. 1 (1991): 1-25.

Smith, James Howard. "Religious Dimensions of Conflict and Peace in Neoliberal Africa: An Introduction." In Displacing the State: Religion and Conflict in Neoliberal Africa, edited by Rosalind I. J. Hackett, R. Scott Appleby, and James Howard Smith. Kroc Institute Series on Religion, Conflict, and Peace Building. Notre Dame: University of Notre Dame Press, 2012. http://helka.linneanet.fi/cgi-bin/Pwebrecon.cgi?BBID = 2517269 .

Ssentongo, Jimmy Spire. "Spaces for Pluralism in 'Ethnically Sensitive' Communities in Uganda The Case of Kibaale District.” PhD diss., University of Humanistic Studies, 2015.

Takyi, Baffour K., Chris Opoku-Agyeman, and Agnes Kutin-Mensah. "Religion and the Public Sphere: Religious Involvement and Voting Patterns in Ghana's 2004 Elections." Africa Today 56, no. 4 (2010): 62-86.

Uganda Bureau of Statistics. "National Population and Housing Census 2014 - Main Report." Kampala, 2016. http://www.ubos.org/onlinefiles/uploads/ubos/NPHC/2014\%20National\% 20Census\%20Main\%20Report.pdf.

UJCC. Preliminary Report on the Presidential and Parliamentary Elections of 2016. Kampala: Uganda Joint Christian Council, 2016.

Ward, Kevin. "Eating and Sharing: Church and State in Uganda." Journal of Anglican Studies 3, no. 1 (2005): 99-120. 